\title{
Knowledge Management Practices and Transformational Leadership Traits: Predicting Process Innovation in FMCG Industry
}

\section{Prácticas de gestión del conocimiento y rasgos de liderazgo transformacional: predicción de la innovación de procesos en la industria de bienes de consumo}

\author{
Ghazi Ben Saad \\ Prince Sattam Bin Abdulaziz University, Alkharj, Saudi Arabia \\ ORCID: https://orcid.org/0000-0002-9154-0680 \\ Saad Al Altheeb \\ Prince Sattam Bin Abdulaziz University, Alkharj, Saudi Arabia \\ ORCID: https://orcid.org/0000-0002-9746-2564 \\ Muzaffar Abbas* \\ Prince Sattam Bin Abdulaziz University, Alkharj, Saudi Arabia \\ ORCID: https://orcid.org/0000-0001-8143-0202
}

Received 02-12-20 Revised 02-25-20 Accepted 06-13-20 On line 06-29-20

*Correspondence

Email:mm.abbas@psau.edu.sa
Cite as:

Ben Saad, G., Al Altheeb, S., Abbas, M (2020). Knowledge management practices and transformational leadership traits: Predicting process innovation in FMCG industry. Propósitos y Representaciones, 8 (SPE2), e662. Doi: http://dx.doi.org/10.20511/pyr2020.v8nSPE2.662 


\section{Summary}

Organizations in the current competitive and challenging situation considered organizational process innovation to sustain themselves with competitive advantage and provisioning of high value products to consumers. The current study investigates the role of transformational leadership traits and knowledge management practices on predicting the process innovation in FMCG companies. Data has been collected from the 10 FMCG companies located in major two cities i.e. Lahore and Karachi, Pakistan. Sample of 200 top line managers have been selected by convenience sampling method and adapted itemized questionnaire has been presented to the top management after a brief session of face to face interviews. Response of 170 top line employees has been registered and statistical testing has been done on SPSS 22. Results indicated that the transformational leadership traits has significantly positive impact on process innovation which effectively expedites the production efficiency of manufacturing units. The knowledge management practices such as acquisition, transfer and application has strong and positively significant association with process innovation. The knowledge management practices positively mediates with transformational leadership traits and resultantly lays foundation for continuous process improvement to survive in market. This conceptual model practically helps the production and manufacturing companies to nurture positive change management attitudes, decreasing production time, expanding products range, development of skills needed to advocate and adopt change, employee involvement, commitment and benefits of large scale economy. This study is limited to FMCGs in major cities and can be expanded to services industry and test the conceptual model.

Keywords: FMCG; Innovation; Knowledge Management; Transformational Leadership; Change; Process Innovation.

\section{Resumen}

Las organizaciones en la actual situación competitiva y desafiante consideraron la innovación de procesos organizacionales para sostenerse con ventaja competitiva y aprovisionamiento de productos de alto valor para los consumidores. El estudio actual investiga el papel de los rasgos de liderazgo transformacional y las prácticas de gestión del conocimiento en la predicción de la innovación de procesos en las empresas de bienes de consumo. Se han recopilado datos de las 10 compañías de bienes de consumo que se encuentran en las dos principales ciudades, es decir, Lahore y Karachi, Pakistán. Se seleccionó una muestra de 200 gerentes de primera línea mediante un método de muestreo de conveniencia y se presentó un cuestionario detallado adaptado a la alta gerencia después de una breve sesión de entrevistas cara a cara. Se ha registrado la respuesta de 170 empleados de primera línea y se han realizado pruebas estadísticas en SPSS 22. Los resultados indicaron que los rasgos de liderazgo transformacional tienen un impacto significativamente positivo en la innovación de procesos, lo que acelera efectivamente la eficiencia de producción de las unidades de fabricación. Las prácticas de gestión del conocimiento, como la adquisición, transferencia y aplicación, tienen una asociación fuerte y positivamente significativa con la innovación de procesos. Las prácticas de gestión del conocimiento median positivamente con rasgos de liderazgo transformacional y, en consecuencia, sientan las bases para la mejora continua de los procesos para sobrevivir en el mercado. Este modelo conceptual prácticamente ayuda a las empresas de producción y fabricación a fomentar actitudes positivas de gestión del cambio, disminuyendo el tiempo de producción, ampliando la gama de productos, desarrollando las habilidades necesarias para abogar y adoptar el cambio, la participación de los empleados, el compromiso y los beneficios de la economía a gran escala. Este estudio se limita a los bienes de consumo en las principales ciudades y se puede ampliar a la industria de servicios y probar el modelo conceptual.

Palabras clave: FMCG, Innovación, gestión del conocimiento, liderazgo transformacional. Cambio, innovación de procesos. 


\section{Introduction}

Companies in today's uncertain and turbulent environment emphasize on developing and nurturing the appropriate leadership traits and behavior to face and overcome the intensive competitive market pressures and strategize to survive in a befitting manner. Transformational leaders develop the innovative organizational capabilities by aiding adequate autonomy to improve organizational learning, choose the manner to execute the activities of jobs, support employees on using all available resources of company to enhance their creativity, encourage organizational learning (Jung et al., 2008; Gumusluoglu \& 1lsev, 2009; Correa et al., 2007).

Nowadays organizations are highly focused on the activities of employees that enhance the knowledge of employees to develop organizational knowledge. Consequently, a knowledge management system is created by the organizations in which knowledge management process is executed with the support of knowledge infrastructure. The outcome of this system converts the resources of the organization into capabilities, which creates value for the organization. The level of organizational innovation can also be improved through the potential of knowledge management practices, apart from transformational leadership. The example includes, the transfer of knowledge among organizational units enhance mutual corporation and organizational learning, which in result helps the organization for new knowledge creation and improvement in innovation (Tsai, 2001).

Theories of knowledge management and transformational leadership have been given more awareness for empirical investigation because of its strong impact on organizational performance and innovation. Moreover, in previous literature studies, the additive impacts of these theories on organizational innovation have adequately been explored. The additive effects of the knowledge management process and transformational leadership on the innovation of product and process management have not been identified in depth. The combined effect of these theories has discussed in the dearth of studies in leadership literature of product and process innovation.

On the same path, conceptual (Figure - 1) model of this study has developed and test of this model has explored from the services firms located in Pakistan. Particularly, the main objective of this study is to observe the impacts of the knowledge management process and transformational leadership on the innovation of organizational product and process, and identify the function of knowledge management process along with its association among organizational product and process innovation and transformational leadership.

\section{Literature Review}

The concept of transformational leadership theory among researchers has not been derived in recent times, the debate of such behaviors development discussion began in the '70s (Burn, 1978). Peterson, Walumbwa, Byron and Myrowitz (2009) defined the transformational leadership as; "leaders who enhance the self-confidence of their employees to understand their potential, positively forecast the future organizational scenarios, working out with employees to find out their needs and participate to fulfil their needs collaboratively and communicate the employees an attainable organizational mission and vision.

Bass (1985) determine four same style behaviors based on definite support of employees which includes individualized consideration, intellectual stimulation, and inspirational motivation and idealized influence and highlighted the impact of these behaviors on fulfilling the higher needs of employees. The leaders enhance the capabilities of employees through inspirational motivation by encouraging employees toward achieving the goals of the organization and set vision and mission for upcoming events of the future. 
Bass and Riggio (2006) describe the combination of inspirational motivation and idealized influence as charismatic leadership behavior. The leaders challenge the employees through intellectual stimulation by different methods of routine task performance and ask the ways through which they used to derive the solutions. Finally, leaders play the role of mentor according to individualized consideration behavior by paying attention to satisfying the needs of employees and sorting out the queries of employees.

Individual employees knowledge is classified by the researchers as follows; know-what (job oriented knowledge, unambiguous and explicit) know-how (tenure-based knowledge, tactics and not easy to express), and disposal knowledge (the combination of intuition, ability, creativity and innovativeness knowledge) (Lowendalhl et al., 2001). Nonaka (1994) found that KM is essential for any organization to create various strategies to transform every single employee knowledge into the knowledge of organization because of the knowledge of individual lies within the brain of employees, and due to this knowledge, he/she creates novelty in knowledge within $\mathrm{him} / \mathrm{herself}$. Sustaining and achieving competitive advantage usually depends on the extent to which organizations manage and leverage every employee's knowledge.

On the same path, knowledge management systems are established by the organizations through which culture, technology and the organizational structure help the organizations to execute the process of knowledge management system from knowledge implementation, transfer and acquisition (Chen \& Huang, 2009). External professional networks, suppliers and customers knowledge acquisition represents knowledge acquisition of any firm; knowledge transfer is also present between employees or unit to gain explicit knowledge from other employee or unit or for the exchange of tactics among employees or units; the process of knowledge application is the implementation of personal knowledge of both employees', customer and suppliers (Filius et al., 2000; Birasnav et al., 2011). Transformation of the traditional firm to an innovative firm is possible through the implementation of activities related to knowledge management process (Darroch, 2005; Chen \& Huang, 2009).

Garcia and Calantone (2002) defined the particular technological innovation as follow; "it is an iterative process originates by the perception of new service opportunity and/or a new market from technology-based invention which leads to striving for marketing tasks, production, and development for the commercial achievement of the invention'. Usually, it has been classified as product and process innovation.

Booner and Walker (2004) and Lukas and Ferrel (2000) describes the types of products innovation as follows; products modifications/ improvements, new-to-the-world product, me-too products and product-line extensions. Moreover, researcher further elaborates that the product has a slight improvement from the old product to new product, so that product is completely new for the current firm or customer market is known as product modification/improvement. If a current research and development team of a firm newly produced a particular product and this product is produced for both industry and market is known as New-to-the-world product. Products which are produced by alteration of particular product specification, which has already been created by the competitors and the secondary product is new for the present firm but not new for the customer market, this old product is known as Me-too product. The products which are produced by extending the current firm product line, and the new line of product is not new for the firm but it is new for the customer is known as product-line extension.

Moreover, to improve the internal process efficiency of product the introduction of new changes during the production of product or services is known as process innovation and it depends on the rates of new technology implementation in the organization (Damanpour \& Gopalakrishnan, 2001). The studies of Lager (2002) categorize process innovation as follows; (1) the process of technological newness to the world shows the extent to which market recognize the particular process technology and (2) the process of technology innovation to the company shows the extent to which a particular process technology is installed in the particular firm 
production system. Process innovation aim is to increase the volume of the product and decrease the cost related to its manufacturing process.

When the level of organizational innovation has increased, the employee's intellectual stimulation behavior is encouraged by the leaders to make a practical framework through which all problems within or outside the context of jobs can be sorted out. This independent thinking and encouragement of employees can transform the portrait leaders into opening leaders, which creates motivation in employee to keep themselves engage in all activities associated with innovation. More solutions and ideas have created by this explorative strategy, which improves the organizational innovations subsequently (Roasing et al., 2011; Jung et al., 2008).

Studies of Bass, Avolio, Jung, and Berson (2003) concluded that leaders like to share and take risky decisions because of their idealized influenced behavior and this support the employee to take risky decisions during any performance of the task. The effectiveness of a risky decision is nurturing during production process alteration, introducing unique services and producing new products. The level of employees' needs is identified through individualized consideration behavior and this helps to develop their potential entirely. Therefore, intrinsic and extrinsic motivation is maintained in employees through monitory and non-monitory rewards provided by the leaders (Zhu et al., 2005; Bass et al., 2003).

The findings of Jung et al. (2008) and Jasky (2004) shows that the antecedent of service quality and firm innovation is intrinsic motivation. Moreover, very supportive culture is maintained and established through a series of leaders activities that helps to get acceptance from stakeholders and it also promotes change management. Consequently, this helps to increase organizational innovation. However, according to Paulsen et al., 2009 the charismatic behavior is present in transformational leaders which help to promote team identity and this increase a commitment between team members which is a cause of better team innovation. This discussion gives more chances to understand that leaders will acknowledge the importance of process innovation and implement these in their firm. The hypothesis is proposed as follows;

Hypothesis 1: There is a significant relationship between transformational leadership traits and process innovation.

Implementation of knowledge management programs is very essential for many firms and their employees are encouraged to participate in these programs, innovative ability provide strength to a firm and it depends upon the intensity of knowledge management process implementation. To elaborate on this debate, Tsai (2001) states that knowledge management process implementation encourages cohesion and learning between organizational units, it also increases the innovation capability of units and raises organizational knowledge. Moreover, Darroch (2005), Chen and Huang (2009) further elaborates that knowledge management process promotes firm innovation, transfer, develops their innovative ability, and involves in the acquisition.

The research study of Holsapple and Jones (2004) states that knowledge acquisition is a method of acquiring knowledge from the external environment in both direct and indirect ways (information gathering from acquiring a firm, recruiting employees, partnering with a research institution, customers and suppliers, magazines and Journals etc) and implement it in the organization. Moreover, studies of Cassiman and Veugelers (2006) shows that the external knowledge can create a positive effect on the efficiency of current organizational activities of research and development while this organization gives high importance for acquiring knowledge.

Research conducted by Lyles and Salk (2007) and Correa et al., (2007) shows that the level of organizational innovation is decided from the extent of learning on acquisition and utilization of such knowledge. The strength of ties between particular firm stakeholders is associated with 
amplifying the intensity of knowledge acquisition. An example includes relational embeddedness in a firm --- the level of association of the firm's network and it's reciprocal with others-- more information acquisition about new product and processes.

Consequently, studies of Rindfleisch and Moorman (2001) shows that the ability of an organization has increased through knowledge acquisition and it also accelerate the new product development process. Studies of Zahra, Ireland and Hitt, (2000) and Tsai (2001) shows that a firm which holds a central position in network and having a large network helps the organization to access resources and external knowledge to speed up it is learning, utilize the knowledge of its customers, launch new product into the market and improve its product.

Currently, organizations through knowledge acquisition enables to reduce the product life cycle length, increase the size of existing knowledge and also develops a commitment of the organization towards customer serving which results in producing more number of new products by the organization (Yli-Renko et al., 2001). The process through which employees or unit gained the knowledge and through the systematic network, this knowledge is shared with other employees and units is known as knowledge transfer. In a firm, the explicit knowledge transfer among employees is experienced through intranets and training programs, whereas the tacit knowledge is transferred from manager to employees through mentor programs support. So, new knowledge is created through this transfer of knowledge and it supports the launching of a new product into the market (Dayasindhu, 2002). Variety of new knowledge is created through knowledge transfer which makes a great impact on the level of innovation. An example includes, A firm maintained a close relationship with another organization and sharing tacit knowledge with that firm creates an immediate impact on the innovative capabilities of that organization. Due to this reason, the exceptionality of tacit knowledge is higher as compared to other competitors of the firm. In contrast, the impact of explicit knowledge transfer intensity is low on the innovative capabilities of an organization because this knowledge is already common in other organizations. Studies of Cavusgil, Calantone and Zhao (2003) supported the above discussion that there are higher innovative capabilities present in America services and manufacturing organizations when the tacit form of knowledge is shared with other organizations by this firm. New ideas can be created through new knowledge by the replacement of old ideas of unit and employees and the capabilities of the organization can be strengthened, which enables the organization to create more customized products by the adjustment of new processes. If the absorptive capacity of employees and units is high then the outcomes will be more strengthened (Tsai, 2001). Research conducted by Shalley, Zhou and Oldham (2004) has found it critical for an organization to encourage higher absorptive capacity in employees because the new ideas created by their colleagues can be quickly absorbed and they may implement those ideas for project completion and also for their purposes or interests. As a result, individual improved creativity can be transformed into innovative products and processes at the organization level through the transfer of knowledge. The innovative capabilities of the organization can be improved by donating knowledge to other members of the organization (Lin, 2007). Research of Chen and Huang (2009) shows the reasons due to which organization give more importance to knowledge application: the application of knowledge is in tacit form; which is not very easy to apply and greater cognitive ability is required for its application; new knowledge is generated through knowledge application and organizational value imparts new products. Sarin and McDermott (2003) conducted a study among 54 teams of new product development, which shows that the knowledge is applied by the team or individual employee, the number of products has been launch by the organizations in the market which have fast decision-making process. The establishment of processes can also be reshaped through fast decision making in the organization. The following hypothesis is derived from the above discussion:

Hypothesis 2: There is a significant relationship present between knowledge management process implementation activities (such as application of knowledge, transfer, acquisitions) and process innovation. 
Birasnav et al., (2011) state that the knowledge supportive culture is established by transformational leaders in the form of developing beliefs, assumptions and set of values related to the knowledge that creates a behavior of employees for the performance of knowledge related activities and knowledge management engagement. Zhu et al., (2005) have been found a significant impact of this culture implementation on sharing of knowledge among employees, both monetary and non-monetary awards could offer to employees for knowledge sharing with others colleagues, which in results launch new products in the market in a cost-effective manner. So, the innovation ability of organization improves through it (Darroch, (2005). According to researchers especially Tanriverdi, (2005), the dependence of knowledge sharing prevalence is on technological abilities of a specific firm. For mission and vision achievement, the importance of integrating workers with technology is to understand by the leaders for transfer of knowledge. To achieve the vision and mission of organizations, the leaders are mostly seen in new technology implementation and design to let the employees understand about its importance, so that the latest technology is used by the employees in the organization. Wang, Chou and Jiang (2005), Schepers, Wetzels and De Ruyter (2005) showed that the advance technology implementation in organization can also provide a chance to employees for unrestricted access to all available resources of organization, so that the employees understand the importance of technology, which is necessary to adapt changes for new product development in less time. Nemanich and Keller (2007) discussed the importance of external knowledge which is communicated by the transformational leaders, improves the creativity of employees by acquiring other organizations.

Research studies of Nemanich and Keller (2007) shows that the organizational goal and vision can be clear through inspirational behavior, which increased the potential of employees for the achievement of goals. Lyles and Salk (2007) concluded that the leader who has definite goals can understand the important external knowledge for their firm which increases the innovative performance of organization due to acquisition of that useful knowledge. Consequently, the newness in a product increases with this knowledge acquisition. Following hypothesis is proposed based on the above argument:

Hypothesis 3: There is positive relationship among transformational leadership traits and process innovation and is enhanced with the implementation of the knowledge management process/practices.

On the basis of extensive literature review the following research framework is constructed.

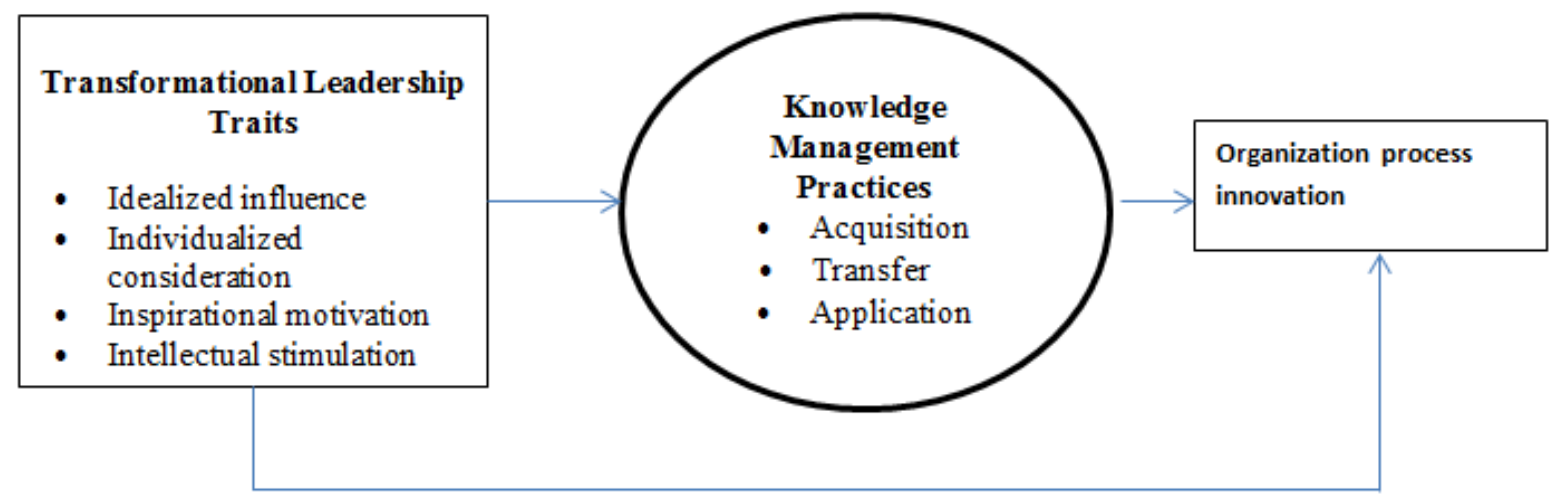

Figure 1. Research Framework

\section{Method}

The current study follows the positivist paradigm and cross sectional in nature. The hypotheses of the current study depicts that FMCG sector is one of the major industry in Pakistan where the 
manufacturing and production of consumer goods adopts and practice the latest technological processes to meet the competitive and fierce market competition. The challenging competitive environment pushes firms to upgrade their current technology or practices and leaving the lethal or malpractices in order to retain their product/process/service efficiency and effectiveness at optimum level. Data has been collected from the targeted population through convenience sampling technique. The questionnaire was adapted from the previous studies and measurement of responses on 5 point likert scale ranges from 1 to 5 ( 1 - Strongly Disagree to 5 - Strongly Agree).

Ten FMCG companies (Unilever Pakistan, DenPak, Habib Oil Mills, Pepsi Cola, Reckit \& Benckisier, Lakson and Tobacco, Kohinoor Mills, Nestle Pakistan, Shezan, and Proctor \& Gamble) have been selected to explore the implication of transformational leadership traits and behaviour of top line managers/leaders in implication of process innovation to bring out the competitive customer preference products or services by effective and efficient process and controls during production process; also the intervention of knowledge management process steps to cultivate synergy and reaching at process effectiveness to bring out the organizational innovation. The sampling frame consists of sampling subjects from the head offices or corporate offices of the aforementioned firms in Faisalabad, Lahore and Karachi in Pakistan.

For data collection, sampling frame subjects constitutes 220 top line managers or leaders who were given questionnaires to enlist how frequently the transformational leaders' behaviour and traits encourages the implication of knowledge management process/ practices and rating the firm's process innovation level.

The itemized questionnaires adapted and the transformational leadership was measured from the most reliable and valid items scale named MLQ (Multi leadership Questionnaire) developed and tested by Bass and Avolio (1995); Knowledge Management Practices scale of 21 items from the studies Filius, Jong, and Roelofs (2000) and process innovation was measured by using 8 items scale adapted from Prajogo and Sohal (2006).

After a period of 18 days, responses of distributed questionnaires came and 196 responses were receieved out of which 170 responses were complete in every aspect. The data was analyzed on SPSS version 22. The statistical tests were applied to see the properties and impact of variables on each other.

\section{Findings \& Results}

Data collected from the survey results was analysed on SPSS and after calculating the normality of data and fulfilling the essential assumptions of data normality by checking mean, median, mode, standard deviation, variance, skewness and kurtosis; the scaled itemized responses have been passed under testing of reliability by calculating cronbatch alpha (Ayes, 1998). The reliability testing shows the legitimacy and genuineness of the items taken into consideration for measurement of variable understood and considered by the sampling subjects (Patten, 2004) also it elucidates the instrument with same items used in different cultural settings giving more or less same results and degree of responsiveness (Miles and Huberman, 1994) based on items operationalization perceived by the sampling subjects as it is defined by researcher(s). The coefficient of cronbatch alpha range $(0-1)$ and it is acceptable as good to excellent if value close to $1(.5-1)$ (Sekaran, 2000).

Table -1 shows the cronbatch alpha value of all the three variables and is above .7 which can be considered good and explains that the items of questionnaire are reliable to proceed for further analysis. 
Table 1.

Reliability Test

\begin{tabular}{cccc}
\hline Variables & Constructs & Estimates & Reliability \\
\hline Organizational Innovation & Process Innovation & .792 & .792 \\
Transformational Leadership Traits & Idealized Influence & .85 & .850 \\
& Individualized & .56 & \\
& Consideration & & \\
& Inspirational & .94 & \\
& Motivation & & \\
& Intellectual Stimulation & .84 & \multirow{2}{*}{ Knowledge Management Practices } \\
& Acquisition & .73 & .774 \\
& Transfer & .52 & \\
& Application & .83 & \\
\hline
\end{tabular}

Table 2.

Estimated Regression Weights

\begin{tabular}{cccccccc}
\hline & & & Estimate & S.E. & C.R. & P & Label \\
\hline KMP & $<---$ & TL & .782 & .0530 & 4.48 & .021 & Supported \\
OI & $<---$ & TL & .699 & .0476 & 10.04 & .001 & Supported \\
OI & $<---$ & KMS & .451 & .0456 & 8.978 & .003 & Supported \\
\hline
\end{tabular}

Table -2 shows that the transformational leadership has $78 \%$ impact on KM practices and it elucidates a positive and highly significant and strong impact of leadership or leader's traits on the knowledge acquisition, sharing and transferring pattern in FMCG companies. If the FMCG top heads and strategic brains don't care about the knowledge management patterns the technology cannot be processed well and latest market demands can't be chased. The influx of information during a specific duration if not used will be time barred and product quality affects which results in decline of market share. Not only this, a single product review downs the overall company reputation and market share will decrease which ultimately keep the performers in challenging position and corporate heads/ leaders are keen to keep pace with the market demand at one end and on other end they are supposed to be intellectually, emotionally, physically become source of inspiration, motivation, considerate to handle situations, taking risks, timely decision making, aligning followers on one page with a core motive to attain company objective to be in right direction and upstanding position.

The beta value shows that if there will be one-unit change in transformational leadership it will bring $78 \%$ which will be a major change in operationalization of knowledge management practices within company. The abovementioned table demonstrated the relationship among transformational leader traits and KM practices is statistically significant due to probabilistic value is 0.05 . Hence $\mathrm{H} 1$ accepted. Table -2 further highlights the impact of transformational leadership on organizational process innovation which in actual creates difference and prominence of the product depends upon how refined and latest the process will be used to manufacture the product. The transformational leader has almost $70 \%$ impact in accomplishing process innovation and the individuality of leader within a firm or manufacturing company cannot be ignored as his role is significant to retain market share and competitive position. Therefore, $\mathrm{H} 2$ accepted.

Table - 2 demonstrates the impact of $\mathrm{KM}$ practices mediatory role in implying transformational leader traits and play its positive and significant role in attaining process innovation which will ensure the FMCG success. Leaders/ corporate heads in FMCG when 
revitalizing or realigning their focus to launch a new product, improves process for quality enhancement it becomes necessary that flow of information will be ensured timely and effectively to run process smoothly. Consumer goods are routinely used at household for individuals and in bulk which keeps the turnover high due to high market demand but if the mediation of knowledge management will not be ensured timely and effectively the process may fail and results will be negative which ultimately declines the market share. Hence, H3 is accepted.

Table 3.

Model Fit Index

\begin{tabular}{cccccc}
\hline Chi/Df & GFI & AGFI & CFI & NFI & RMSEA \\
\hline 5.12 & .867 & .788 & .877 & .821 & .081 \\
\hline
\end{tabular}

Table -3 shows the model fit indices which shows the goodness of fit (GFI) is $86 \%$ and model is fit to be imply on the FMCG industry. This model has fit indices closer to 1 which shows the strength of the tested model (Tabachnick, 2007; Diamantopoulos, 2000) and governs that the sampling data is in best fitting (McDonald, 2002; Jöreskog, 1993) on proposed theories of knowledge resources and transformational leadership in organizational setting. The values of GFI, AGFI, CFI, NFI, TLI and PFI becomes close to 1 shows the goodness of priori model fits well on the data and proposed theory (Jeremy, 2009; Brown, 2006; Siguaw, 2000).

\section{Discussion \& Conclusion}

In three ways this study has extended the previous research studies and contributed to the literature. Firstly, there is a significant relationship present between transformational leadership and product and process innovation. The transformation of the traditional firm into an innovative firm is understood by transformational leadership only when a firm has developed its human capital. Empowerment is frequently exercised in organizations to create its human capital so the employee's decision making is quicker on changing product design and production processes. Consequently, the innovative performance of employees has improved through it. Employees' capabilities are transformed into organizational capabilities.

Leaders intellectual stimulation behavior understands the connection among innovation and risk-taking and they discourage the employees on solving job problems in routine ways, despite they give their employees enough confidence to take risky decisions and activities. Meanwhile, when the outcome of those risky decisions are unfavorable these leaders avoid to criticize their employees in front of other people and they also use to maintain their behavior in public.

Secondly, there is a significant relationship present between knowledge acquisition, application and transfer has positive and strongly significant with process innovation. The initiations of knowledge transfer are in the shape of answering the tricky job questions or asking about particular information for decision making associated with development, specifications and new product design. Moreover, in services firms it is a common practice to assign a task in teamwork concept, to involve and develop them in the form of networking.

Firms maintain market shares service firms offer a variety of new products and promote collaborative problem solving, which requires explicit knowledge and tactics. Service employees depend upon the experience of other employees to sort out the customer's problems because they have gone through a similar situation previously and they usually use to work very close to their customers. These employees create newness to the products and services of customers by getting this useful knowledge and ideas from the integration of knowledge transfer and new knowledge from their external environment and experiences. 
Mostly, service firms add newness in their processes and technologies through the knowledge acquisition process. For example, service firms of Pakistan are mostly seen that they observe the introduction of new technologies in other firms and these firms are joined together in many locations. Different managers personally interact with one another and acquire knowledge from their networking behaviours.

Service firms usually get feedback from customers very easily for the improvement of their processes and new process development because the location of these firms is very near to their customers and suppliers. On the same path, it is assumed that these organizations may require the support of suppliers for the introduction of the latest technology in their processes. Studies of Handfield, Ragatz, Petersen and Monczka (1999) shows that the production cycle time has reduced through the integration of suppliers with the internal process of the organization. Moreover, the degree at which organizational expertise reflects in the products and services usually relies on the level at which knowledge is applied efficiently. Sarin and McDermott (2003) study shows that the pace at which the internal processes are updated and products reach the market depends upon the ability of knowledge application.

The responsibility of knowledge application is on a team or on an individual employee, which was acquired or gathered so fewer mistakes will happen and becomes reason for the rapid decision in the organizations. Therefore, the impact of knowledge application on process innovation is significant. Results confirms that there is complete mediation of knowledge application and knowledge transfer among transformational leadership and process innovation. Hence, transformational leaders influence employees for goal achievement and command the problem solving of employees and influence the firm by occupying a central position in the informal command. Due to this, knowledge and information within the network is transferred from leaders to employees of the organization. The employee's innovative performance can be influenced by direct and personalized mentoring ability during knowledge sharing.

Essentially, assumptions are always questioned by the intellectual stimulation behavior and employees seek innovative solutions for the old problems of the organization. Every firm expects the prevalence of knowledge and the most essential part is to reward employees on knowledge sharing. These leaders are recognized for follower's empowerment and they involved employees in the new product team for decision making autonomy and freedom. The introduction of new products in the market is quicker for taking immediate decision making on product design. The high concentration of transformational leaders is on knowledge acquisition from external sources which includes research institution, customers and suppliers. To develop new technologies, large service organizations usually worked with institutions, get feedback from customers for product designing, and engage suppliers for the improvement of product quality to remove unnecessary processes.

Fredendall, Hopkins and Bhonsle, (2005), Bass and Riggo (2006) provides evidence that transformational leaders and visionary leaders who continuously acquire knowledge and keep their relationship with their suppliers to improve delivery performance and quality of the product. These leaders have found more constructive to launce modern technologies and create a flexible internal process to produce diversity in products. The integration of existing knowledge and new knowledge is experienced through these technologies which help employees to use the combination of both pieces of knowledge into the internal processes.

Transformational leaders usually supporting employees to improve the learning capability of the organization, improving productivity and encourage the organizational transformation. Learning in the organization is created by transformational leaders-- implementation of latest process and product is quicker in organizations which encourages employees for continues learning adaptation of products or processes (Maersick and Watkins, 2003; Bass, 2000). As a 
result, levels of process innovations are improved positively in organizations in which employees are encouraged for adaptations.

The value of leadership literature is contributed by the study through its three results. First, the influence of transformational leadership is found on product innovation and process innovation of the organization. The concept of innovations and leadership relationship is explored by this study separately, usually, innovation is studied individually in previous research. Second, there is a significant association present among the variables of the knowledge management process and process innovation and product innovations. Moreover, knowledge application and knowledge transfer were associated with product innovation, whereas knowledge application and knowledge acquisition were related with process innovation. Third, by encouraging knowledge application and knowledge transfer the transformational leaders can develop the product innovation which is reported in the above study. However, the involvement of leaders in knowledge acquisition from other organization working externally and improves the process of innovation through the new knowledge application. There is also some particular limitation while adding literature to this study, and consequently, to generalize the results of this study, it is required to do some cautions by all services firms. First, Human resource manager of the firm should measure the responses for knowledge management process and transformational leadership, and while data analyses it is necessary to avoid common method bias elimination. Second, certain sectors of services should not be included in responses, for example, public educational institutions and airlines organizations, and consequently, the study doesn't include the whole population. Third, instead of objective measures, this study is more concerned with the subjective measure of process innovation. Finally, interrelationship and knowledge management infrastructure among knowledge application, knowledge transfer and knowledge acquisition were not included in the above discussion.

\section{Practical Implications}

Managers have several practical implications from this study:

1. Transformational leadership traits should be developed at all managerial tiers in organizational setting with keen locus of control by HR professionals who have to take necessary actions inorder to develop leadership qualities within personnel through need based training programs, practices and cultivate synergy within organization.

2. Nemanich and Keller (2007) highlighted that the leadership style is core and essential to cultivate change, managing and freezing it with culture. Leadership style maintains the aura of the organization and their continuous practices personifies its culture which remains constant and companies respond to the swift changes. The resonance in competitive global market, volatility in government policies in Pakistan only a leader with exceptional motivational skills and influential characteristics can stimulate the followers to acquire, store, imply and transfer knowledge for best results of strategic intention to achieve company goals and strategize to improve the organizational performance.

3. Top line managers should integrate the HR and KM strategy to make process innovations. A well-structured reward strategy should be formulated by the managers to share, acquire and apply knowledge. The involvement of employees in the KM process should be assured in the process of performance appraisal. If employees recognize that involvement in knowledge activities is related to career success, then the innovations of the firms will be improved and it will also help to create organizational knowledge.

4. Finally, there is a significant relationship present between KM process and organizational innovations, efforts should be made to develop inter and intra organizational networks and importance of participating in these should be communicated to employees. Continuous employee assessment about the participatory activities should be kept observed by HR officials in the organization. During the knowledge application employees should be keenly monitored for solving job problems and project execution. 
Organizational innovations can be improved by new knowledge only when it is efficiently applied by the employees.

\section{Future Aspirations}

In future, knowledge management infrastructure role of mediation will be considered in the association among process innovation and transformational relationship, and the variables of knowledge management system interrelationships will be also discovered. Moreover, to predict competitive advantage the association of knowledge management process and transformational leadership could also be extended in future.

\section{Acknowledgement}

This research publication was supported by the Deanship of Scientific Research at Prince Sattam bin Abdulaziz University, AlKharj, Saudi Arabia.

\section{References}

Aragon-Correa, J. A., Garcia-Morales, V. J., \& Cordon-Pozo, E. (2007). Leadership and organizational learning's role on innovation and performance: Lessons from Spain. Industrial Marketing Management, 36, 349-359.

Baron, R., \& Kenny, D. (1986). The moderator-mediator variable distinction in social psychological research: Conceptual, strategic and statistical considerations. Journal of Personality and Social Psychology, 51, 1173-1182.

Bass, B. M. (1985). Leadership and performance beyond expectations. New York: The Free Press.

Bass, B. M. (2000). The future of leadership in learning organizations. Journal of Leadership Studies, 7, 18-40.

Bass, B. M., \& Avolio, B. J. (1995). The multifactor leadership questionnaire 5X short form. Redwood City: Mind Garden.

Bass, B. M., \& Riggio, R. E. (2006). Transformational leadership. Mahwah: Lawrence Erlbaum Associates.

Bass, B. M., Avolio, B. J., Jung, D. I., \& Berson, Y. (2003). Predicting unit performance by assessing transformational and transactional leadership. Journal of Applied Psychology, $88,207-218$.

Batelco (2013). Batelco Launches Entrepreneurs Support Programme at ideas Centre. Retrieved from http://www. batelco.com/batelco cms/NewsStory.aspx?nid=1167

Birasnav, M., Rangnekar, S., \& Dalpati, A. (2011). Transformational leadership and human capital benefits: The role of knowledge management. Leadership \& Organization Development Journal, 32, 106-126.

Bonner, J. M., \& Walker, O. C., Jr. (2004). Selecting influential business-to-business customers in new product development: Relational embeddedness and knowledge heterogeneity considerations. Journal of Product Innovation Management, 21, 155-169.

Bono, J. E., \& Anderson, M. H. (2005). The advice and influence networks of transformational leaders. Journal of Applied Psychology, 90, 1306-1314.

Burns, J. M. (1978). Leadership. New York: Harper \& Row. Cassiman, B., \& Veugelers, R. (2006). In search of complementarity in innovation strategy: Internal R\&D and external knowledge acquisition. Management Science, 52, 68-82.

Cavusgil, S. T., Calantone, R. J., \& Zhao, Y. (2003). Tacit knowledge transfer and firm innovation capability. Journal of Business \& Industrial Marketing, 18, 6-21.

Cefis, E., \& Marsili, O. (2006). Survivor: The role of innovation in firms' survival. Research Policy, 35, 626-641. 
Chen, C., \& Huang, J. (2009). Strategic human resource practices and innovation performance: The mediating role of knowledge management capacity. Journal of Business Research, 62, 104-114.

Damanpour, R., \& Gopalakrishnan, S. (2001). The dynamics of the adoption of product and process innovations in organizations. Journal of Management Studies, 38(1), 45-65.

Darroch, J., (2005). Knowledge Management, innovation, and firm performance. Journal of Knowledge Management, 9, 101-115.

Dayasindhu, N. (2002). Embeddedness, knowledge transfer, industry clusters and global competitiveness: A case study of the Indian software industry. Technovation, 22(9), 551560.

Filius, R., De Jong, J. A., \& Roelofs, E. C. (2000). Knowledge management in the HRD office: A comparison of three cases. Journal of Workplace Learning, 12, 286-295.

Filius, R., Jong, J. A. D., \& Roelofs, E. C. (2000). Knowledge man- agement in the HRD office: A comparison of three cases. Journal of Workplace Learning, 12, 286-295.

Fredendall, L. D., Hopkins, C. D., \& Bhonsle, A. (2005). Purchasing's internal service performance: Critical external and internal determinants. Journal of Supply Chain Management, 41(2), 26-38.

Garcia, R., \& Calantone, R. (2002). A critical look at technological innovation typology and innovativeness terminology: A literature review. Journal of Product Innovation Management, 19, 110-132.

Gumusluoglu, L., \& Ilsev, A. (2009). Transformational leadership, creativity, and organizational innovation. Journal of Business Research, 62, 461-473.

Handfield, R. B., Ragatz, G. L., Petersen, K. J., \& Monczka, R. M., (1999). Involving suppliers in new product development. California Management Review, 42(1), 59-82.

Holsapple, C. W., \& Jones, K. (2004). Exploring primary activities of the knowledge chain. Knowledge and Process Management, 11, 155-174.

Inam, A., \& Authority, P. T. (2016). Foreign Direct Investment in Pakistan Telecommunication Sector. Economic Survey, 7.

Jaskyte, K. (2004). Transformational leadership, organizational culture, and innovativeness in nonprofit organizations. Nonprofit Management and Leadership, 15, 153-168.

Judge, T. A., \& Piccolo, R. F. (2004). Transformational and transactional leadership: A metaanalytic test of their relative validity. Journal of Applied Psychology, 89, 755-768.

Jung, D., Wu, A., \& Chow, C. W. (2008). Towards understanding the direct and indirect effects of CEOs' transformational leadership on firm innovation. Leadership Quarterly, 19, 582594.

Kaliaropoulos (2013). Communication Horizons. Retrieved from http://www.proudlyarabian.com/Bahrain/Batelco-TopTelecommunicationsCompany.aspx\#

Kark, R., Shamir, B., \& Chen, G. (2003). The two faces of transformational leadership: Empowerment and dependency. Journal of Applied Psychology, 88, 246-255.

Khan, M. I. (2010). Feasibility Study of NayaTel (Pvt) Ltd (Doctoral dissertation, Bahria University Islamabad Campus).

Lager, T. (2002). A structural analysis of process development in process industry A new classification system for strategic project selection and portfolio balancing. $R \& D$ Management, 32, 87-95.

Laursen, K., \& Salter, A. (2004). Searching high and low: What types of firms use universities as a source of innovation? Research Policy, 33, 1201-1216.

Lin, F. H. (2007). Knowledge sharing and firm innovation capability: An empirical study. International Journal of Manpower, 28, 315-332.

Lin, H. F., \& Lee, G. G. (2005). Impact of organizational learning and knowledge management factors on e-business adoption. Management Decision, 43, 171-188.

Lowendahl, B., Revang, O., \& Fosstenlokken, S. (2001). Knowledge and value creation in professional service firms: A framework for analysis. Human Relations, 54, 911-931.

Lukas, B. A., \& Ferrell, O. C. (2000). The effect of market orientation on product innovation. Journal of the Academy of Marketing Science, 28, 239-247. 
Lyles, M. A., \& Salk, J. E. (2007). Knowledge acquisition from foreign parents in international joint ventures: An empirical examination in the Hungarian context. Journal of International Business Studies, 38, 3-18.

Marsick, V. J., \& Watkins, K. E. (2003). Demonstrating the value of an organization's learning culture: The dimensions of the learning organization questionnaire. Advances in Developing Human Resources, 5, 132-151.

Nemanich, L., \& Keller, R. (2007). Transformational leadership in an acquisition: A field study of employees. Leadership Quarterly, 18, 49-68.

Nonaka, I. (1994). A dynamic theory of organizational knowledge creation. Organization Science, 5, 14-37.

Paulsen, N., Maldonado, D., Callan, V. J., \& Ayoko, O. (2009). Charismatic leadership, change and innovation in an R\&D organization. Journal of Organizational Change Management, $22,511-523$.

Peterson, S. J., Walumbwa, F. O., Byron, K., \& Myrowitz, J. (2009). CEO positive psychological traits, transformational leadership, and firm performance in high technology start-up and established firms. Journal of Management, 35, 348-368.

Prajogo, D. I., \& Sohal, A. S. (2006). The integration of TQM and technology/R\&D management in determining quality and innovation performance. Omega, 34(3), 296-312.

Rindfleisch, A., \& Moorman, C. (2001). The acquisition and utilization of information in new product alliances: A strength of ties perspective. Journal of Marketing, 65, 1-18.

Rosing, K., Frese, M., \& Bausch, A. (2011). Explaining the heterogeneity of the leadershipinnovation relationship: Ambidextrous leadership. The Leadership Quarterly, 22, 956--974.

Sarin, S., \& McDermott, C. (2003). The effect of team leader characteristics on learning, knowledge application, and performance of cross-functional new product development teams. Decision Sciences, 34, 707-739.

Schepers, J., Wetzels, M., \& De Ruyter, K. (2005). Leadership styles in technology acceptance: Do followers practice what leaders preach? Managing Service Quality, 15, 496-508.

Shalley, C. E., Zhou, J., \& Oldham, G. R. (2004). The effects of personal and contextual characteristics on creativity: Where should we go from here? Journal of Management, 30, 933-958.

Shipton, H., West, M., Parkes, C., \& Dawson, J. (2006). When promoting positive feelings pays: Aggregate job satisfaction, work design features, and innovation in manufacturing organizations. European Journal of Work and Organisational Psychology, 15(4), 404430.

Sosik, J. J., Godshalk, V. M., \& Yammarino, F. J. (2004). Transformational leadership, learning goal orientation, and expectations for career success in mentor-protégé relationships: A multiple levels of analysis perspective. Leadership Quarterly, 15, 241-261.

Srivastava, A., Bartol, K. M., \& Locke, E. A. (2006). Empowering leadership in management teams: Effects on knowledge sharing, efficacy, and performance. Academy of Management Journal, 49, 1239-1251.

Tanriverdi, H. (2005). Information technology relatedness, knowledge management capability, and performance of multibusiness firms. MIS Quarterly, 29, 311-334.

Tsai, W. (2001). Knowledge transfer in intraorganizational networks: Effects of network position and absorptive capacity on business unit innovation and performance. Academy of Management Journal, 44, 996-1004.

Wang, E., Chou, H., \& Jiang, J. (2005). The impacts of charismatic leadership style on team cohesiveness and overall performance during ERP implementation. International Journal of Project Management, 23, 173-180.

Yli-Renko, H., Autio, E., \& Sapienza, H. (2001). Social capital, knowledge acquisition and knowledge exploitation in young technology-based firms. Strategic Management Journal, 22, 587-613. 
Zahra, S. A., Ireland, R. D., \& Hitt, M. A. (2000). International expansion by new venture firms: International diversity, mode of market entry, technological learning, and performance. Academy of Management Journal, 43, 925-950.

Zhu, W., Chew, I. K. H., \& Spangler, W. D. (2005). CEO transformational leadership and organizational outcomes: The mediating role of human capital-enhancing human resource management. Leadership Quarterly, 16, 39-52. 